\title{
Clinical and Therapeutic Management of Male Infertility in Thies, Senegal
}

\author{
Yoro Diallo, Modou Diop N'diaye, Saint Charles Kouka, \\ Mama Sy Diallo, Mehdi Daher, Amy Diamé, Modou Faye, \\ Néné Mariama Sow, Ramatoulaye Ly, Cheikh Diop, \\ Seydou Diaw, Cheickna Sylla
}

Department of Urology, Faculty of Health Sciences, University of Thies, Thies, Senegal

Email: yorodiallo@hotmail.com

How to cite this paper: Diallo, Y., N'diaye, M.D., Kouka, S.C., Diallo, M.S., Daher, M., Diamé, A., Faye, M., Sow, N.M., Ly, R., Diop, C., Diaw, S. and Sylla, C. (2019) Clinical and Therapeutic Management of Male Infertility in Thies, Senegal. Open Journal of Urology, 9, 1-10.

https://doi.org/10.4236/oju.2019.91001

Received: November 5, 2018

Accepted: January 11, 2019

Published: January 14, 2019

Copyright $\odot 2019$ by author(s) and Scientific Research Publishing Inc. This work is licensed under the Creative Commons Attribution International License (CC BY 4.0).

http://creativecommons.org/licenses/by/4.0/

\begin{abstract}
Objective: To evaluate the clinical and therapeutic aspects of male subfertility in the Region of Thies. Patients and methods: This is a retrospective and analytical study involving patients followed for subfertility over a period of 4 years from January 2013 to November 2017 at the level of 3 health structures in the region of Thies. Results: During the period, we collected 201 patients. The average age was $38 \pm 8.4$ years with a greater distribution in the age group 30-39 years. Primary subfertility was predominant with $81.1 \%$ of cases. The average duration was 5 years. We found a history of urethritis (4\%) and orchiepididymitis (2.5\%). Thirty-three percent of patients presented a varicocele (67 cases). Cryptorchidism was recorded in $2 \%$ of cases, testicular hypotrophy in $18.4 \%$ and testicular atrophy in $1.5 \%$. The spermogram identified oligospermia-like abnormalities in $40.8 \%$ of cases, azoospermia $22.4 \%$, and hypospermia $4 \%$. For the qualitative abnormalities, we recorded cases of asthenospermia in $60.2 \%$ of the cases or 121 patients, a necrospermia $58.2 \%$ and a teratospermia $20.4 \%$. A combination of these abnormalities was also reported as astheno-necrospermia in $19.4 \%$ of cases, oligo-astheno-necrospermia $14.4 \%$, oligo-asthenotera-necrospermia $10 \%$ and oligo astero-teratospermia in $2.5 \%$. An assessment of FSH, LH and testosterone was performed in $5.9 \%$ of the cases, or 12 patients. Varicocelectomy was performed in $68.4 \%$ of cases 19 patients, and (medically) assisted procreation in 2 patients. We recorded 13 cases of pregnancy. Conclusion: Male hypofertility is a real problem of management, and requires a particular approach.
\end{abstract}

\section{Keywords}

Hypofertility, Clinical, Spermogram, Varicocele 


\section{Introduction}

Male hypofertility is an inability for a couple to become pregnant after at least 12 months of unprotected sex, for which the male is responsible [1]. These sexual intercourses must be normal in frequency and quality within a couple living regularly together [2]. Spousal hypofertility is a more frequent reason for consultation in daily practice. At present, the number of subfertile couples is estimated at between 60 and 80 million, or about 15\% of couples of childbearing age [3] [4]. Responsibility is shared with a big part imputed to the man, however, in our context, there is an empirical belief that the woman bears all the responsibility. Moreover, in the literature, it is clearly established a male responsibility of at least $60 \%$ of cases divided as follows: $20 \%$ of cases of exclusively male origin and $40 \%$ of mixed origin [5]. The difficulty concerns the recruitment of patients and the coordination of different authors at the level of reference centers during the study period. The purpose of this study is to evaluate the epidemiological, clinical and therapeutic aspects of male subfertility in the Region of Thies.

\section{Patients and Methods}

This is a retrospective and analytical study over a period of 4 years from January 1, 2013 to November 30, 2017. This study was carried out in the main urology centers of the region including the regional hospitals of Thies, Saint Jean de Dieu and EPS of Mbour. The study resulted in the collection of 201 patients. Patients followed in these services for subfertility dating at least 1 year were included. Patients who were lost to follow-up or incomplete files were excluded. Parameters studied: age, duration of desire for paternity, type of subfertility, medical-surgical history, clinical examination data, spermogram results, hormonal assays, ultrasound data, treatment initiated and follow-up of the patient. Patients were followed over a period of 1 to 3 years. The forms were completed by running a file or by direct interview. The varicocele course consisted of a classic inguinal top followed by ligation of the dilated veins

Data was entered and analyzed on the 2010 version of Microsoft Excel software and IBM SPSS software.

\section{Results}

Our study made it possible to collect 201 patients. More than half were recruited in the city of Thies at Saint Jean of God and Regional hospital with 116 patients, or $57.7 \%$. The rest of the patients were registered in Mbour with $42.3 \%$ of cases. The average age was 38 years old with extremes ranging from 24 to 63 years old for a standard deviation of 8.4. Hypofertility was more common in the $30-39$ age group (Figure 1).

The most found occupational categories were teachers with $10.4 \%(\mathrm{n}=21)$, followed by drivers with $8.5 \%(n=17)$. Merchants and fishermen accounted for $7 \%(\mathrm{n}=14)$ and $4 \%(\mathrm{n}=8)$ respectively.

The circumstances of discovery were not specified in $16.4 \%(\mathrm{n}=33)$. Nearly 
half of the patients were referred by a gynecologist $(42.3 \%)(\mathrm{n}=85)$. The patients came of their own will in $33.8 \%$ of the cases $(n=68)$. They were referred by a paramedic (midwife or nurse) in $4 \%$ of cases or a general practitioner in $3 \%$ of cases (Figure 2).

Subfertility was primary in $81.1 \%(\mathrm{n}=163)$ and secondary in $18.9 \%$ of cases. Primary hypofertility predominated in all centers (Figure 3 ).

The average duration was 5 years with extremes of 1 to 30 years and a standard deviation of 4.5 (Figure 4).

We found an orchiepididymitis in 5 patients or $2.5 \%$ and urethritis in 8 patients or $4 \%$ of cases. HTA was found in 6 patients, or $3 \%$ of cases. Four patients underwent a testicular lowering during childhood. An inguinal hernia repair was noted in 3 patients, $1.5 \%$ of cases. One patient was operated on hypospadias. The antecedent of familial hypofertility was found in $2 \%$ of the cases, or 4 patients. Hypofertile brothers were found in $1.5 \%$ of cases.

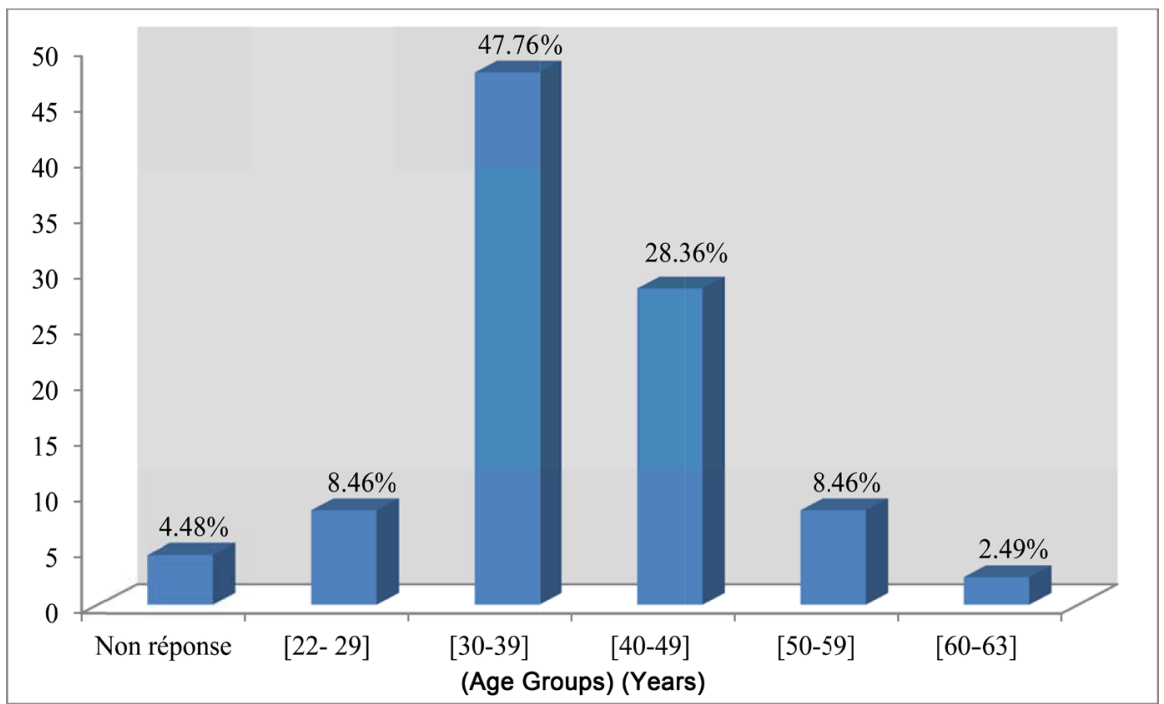

Figure 1. Distribution of patients by age group.

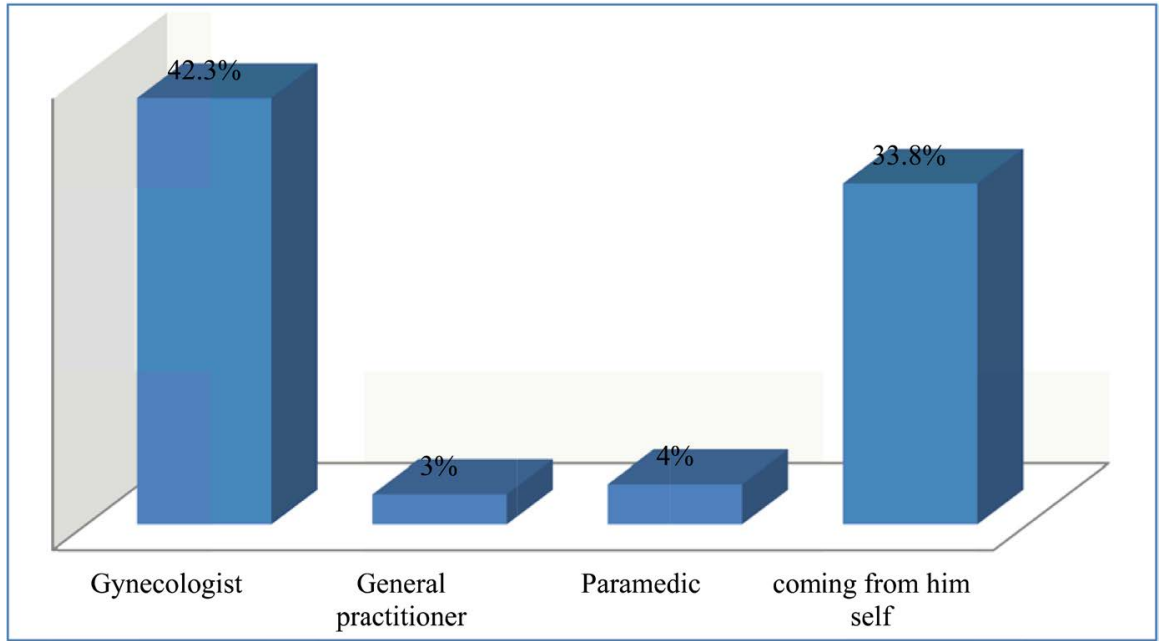

Figure 2. Distribution of patients according to the circumstances of discovery. 


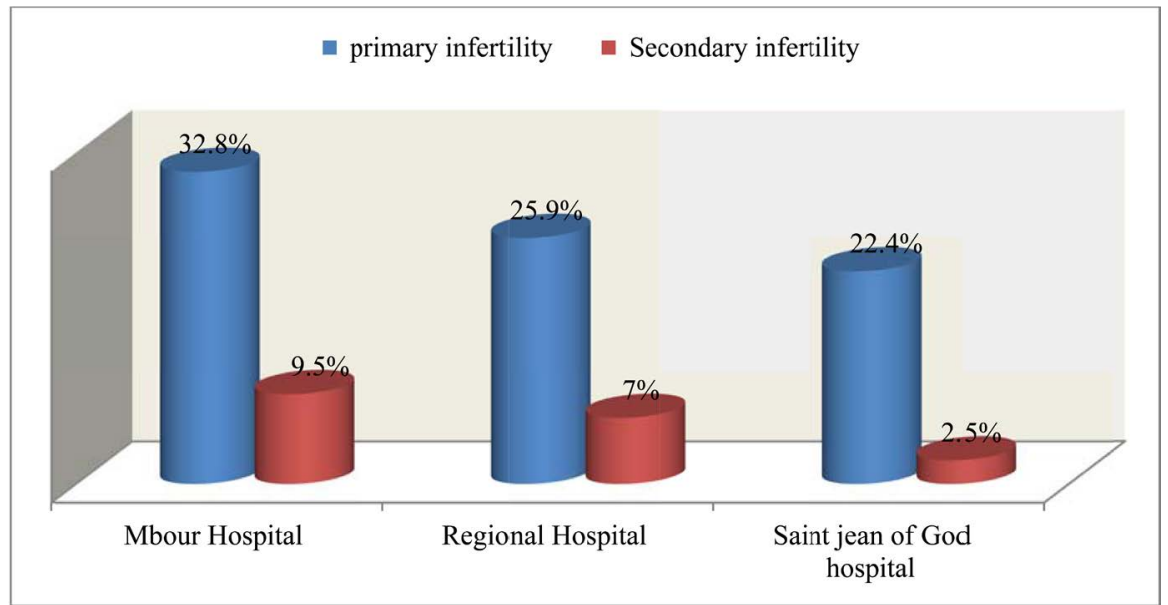

Figure 3. Distribution of the workforce by centers and type of infertility.

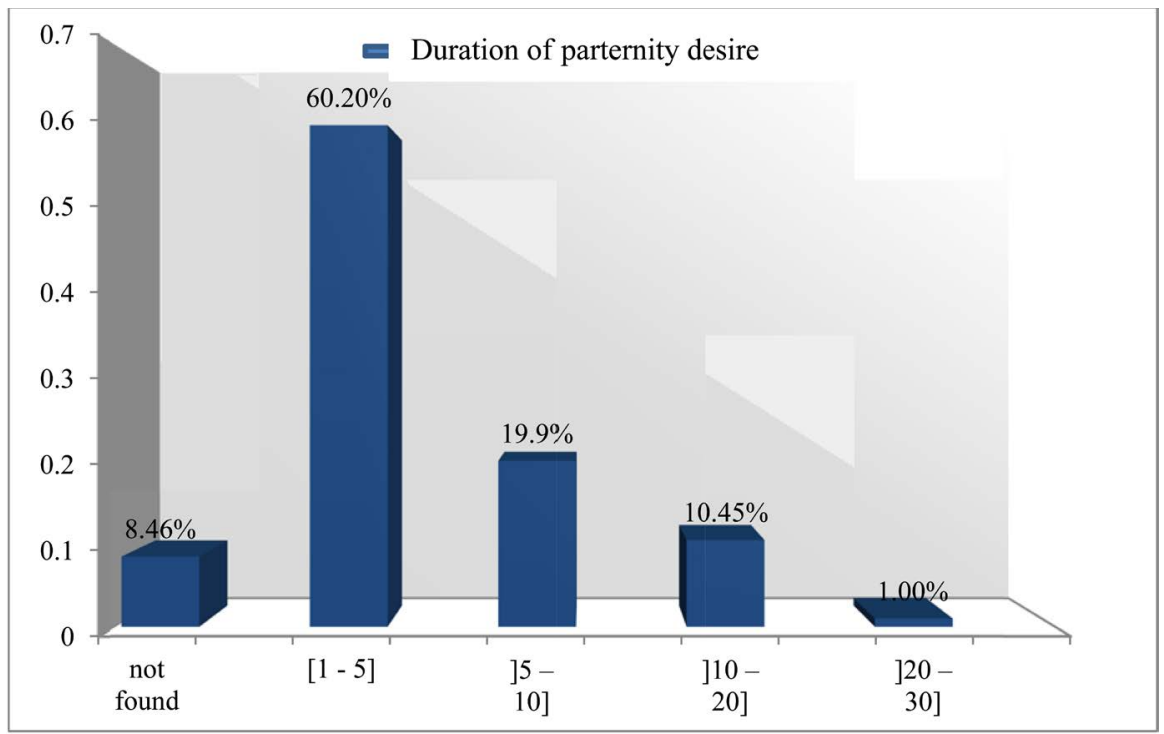

Figure 4. Distribution of patients by duration of subfertility.

The notion of smoking was found in 11 patients or $5,5 \%$ of cases and alcoholism in 3 patients is 1, 5\% of cases. Pesticide poisoning was noted in 5 patients, or $2.5 \%$. Herbal medicine was mentioned by 9 patients or $4.5 \%$ of cases for an average of 6 months.

On examination, we noted 4 cases of cryptorchidism in 4 patients or $2 \%$. In $80.1 \%$ of patients $(n=161)$ the testis was normal size. A unilateral or bilateral testicular hypotrophy was found in 37 patients or $18.4 \%$ and testicular atrophy in 3 patients is $1.5 \%$ of cases. Primary hypofertility was associated with testicular hypotrophy in $15.9 \%$ of cases and testicular atrophy in $1 \%$ of cases respectively, while secondary hypofertility was accompanied respectively by testicular hypotrophy in $1.5 \%$ of cases and testicular atrophy in $0.5 \%$ of cases. Varicocele was found in 67 patients, or $33.3 \%$ of patients. It was bilateral in $19.4 \%(\mathrm{n}=39)$ and unilateral in $13.9 \%(\mathrm{n}=28)$. For unilateral varicoceles, left-sided involvement was predominant. 
Primary infertility was accompanied by varicocele in $27.3 \%$, the location was bilateral in $16.9 \%(\mathrm{n}=34)$ and unilateral in $10.4 \%(\mathrm{n}=21)$. While secondary infertility was accompanied by varicocele in $6 \%(\mathrm{n}=$ cases, the location is bilateral in $2.5 \%$ of cases and unilateral in $3.5 \%$.

Asthrenospermia was found in 121 patients, or $60.2 \%$. Teratospermia was found in $20.4 \%(n=41)$ of the cases. Necrospermia was found in $58.2 \%$ of the cases in 117 patients.

Hypospermia was found in 8 patients ( $4 \%$ of cases), oligospermia in 82 patients (40.8\%). Azoospermia was noted in 45 patients, or $22.4 \%$.

Oligospermia was present in varicocele carriers at $17.4 \%$ compared with $22.9 \%$ in non-carriers. Azoospermia was more widely reported in non-varicocele carriers at $16.4 \%$ than in others (Figure 5).

Astheno-necrospermia was the association most found in $19.4 \%$ of cases $(\mathrm{n}=$ 39). It is followed by oligo-astheno-necrospermia and oligo-astheno-terato-necrospermia with respectively $14.4 \%$ and $10 \%$ of cases (Figure 6 ).

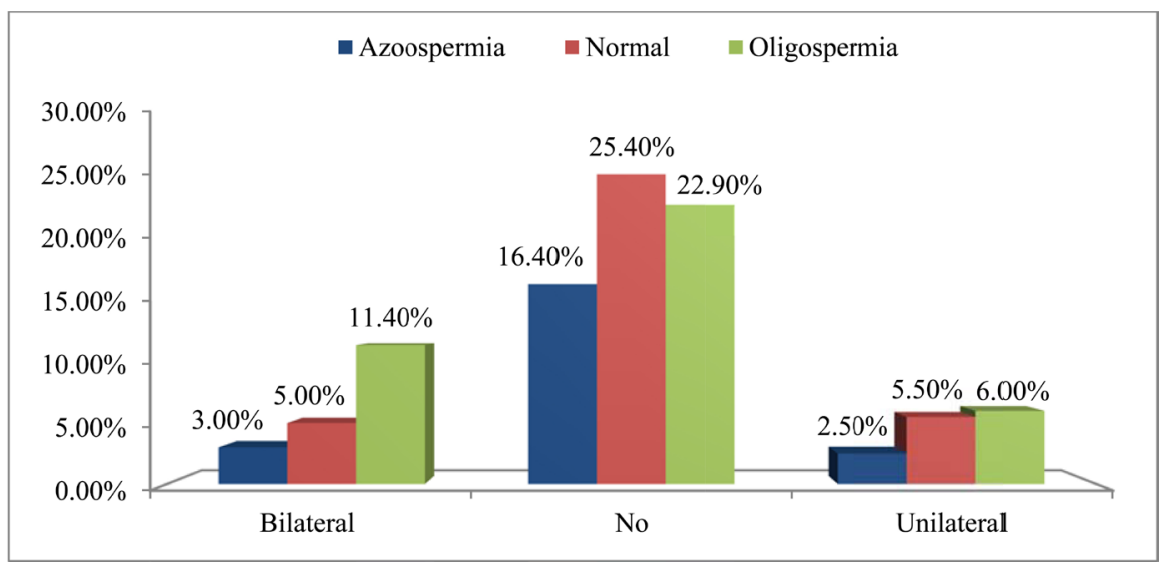

Figure 5. Sperm count and varicocele.

- Association of anomalies spermogramme"

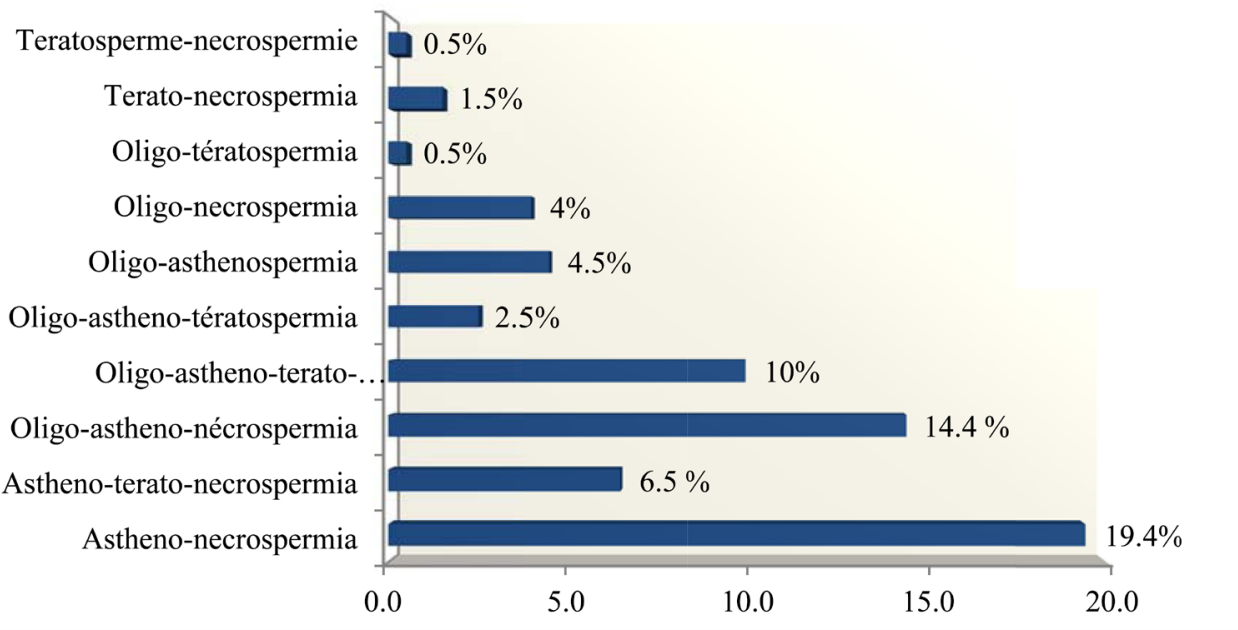

Figure 6. The associations of anomalies with spermogram. 
Spermoculture has found a germ in $2 \%$ of cases $(n=4)$. These germs were Chlamydia trachomatis, Escherichia coli, or gram negative. Hormones (FSH, LH and testosterone) were measured in patients with azoospermia or severe oligospermia in 44 patients $(22.4 \%)$. FSH was increased in 10 cases or $22.2 \%$ of cases of azoospermia.

Ultrasonography was performed in all patients and revealed the presence of unified or bilateral varicocele in $33.3 \%$ of patients $(n=67)$, testicular hypotrophy in 6 patients, and 2 patients with testicular atrophy.

All the patients had a medical treatment based on Vitamin E therapy. Varicocelectomy was the main indication for surgery; it was performed in $9.5 \%$ of cases ( $n=19$ ). The cure concerned both sides in $96.5 \%$ of cases. The classical open surgical approach by inguinal approach was the only technique performed. A patient was able to benefit from in vitro fertilization.

The duration of follow-up of the patients varied between 1 and 4 years. A spermogram of control between 3 and 9 months was performed in all patients after treatment. We found 16 cases of normalization of all spermatic parameters.

In $28 \%$ of patients, there was deterioration of the spermogram and in $30 \%$ of the cases improvement of it. In the follow-up we recorded 13 pregnancies including 11 live births.

\section{Discussion}

Male responsibility for infertility is well known. In the literature, this responsibility is in $20 \%$ of the cases exclusive to the man and shared in $40 \%$ of the cases [5]. It poses a real problem in the stability of a couple especially in our context where the birth of a child represents a decisive phase in married life.

Patients are usually young adults in the 30 and 50 age groups. Indeed, Niang [6] found an average age of 39 years and a predominance of the age group 30-45 years as well as Sakande [7] with an average of 37 years and an age group more represented between 30 and 39 years. Wallerand [8] found an average age of 34 years. They are also comforted by the work of Diallo [9] which has found substantially the same results. Eisenberg [10] found an average age of 35 years \pm 5.8 with a clear predominance in the age group 30 - 39 years or $60.7 \%$. These results are comparable to those found in our study with an age range of 30 - 39 years with an average age of 38 years.

The most frequent professional classes were teachers followed by drivers. Benazzouz [11], on the other hand, found significantly different results with the workers at $38 \%$ as the most frequent professional class followed by civil servants with $32 \%$, while Sakande [7] had in these works traders as the main professional category with $45 \%$, followed by workers $21 \%$ and farmers in $16 \%$ of cases.

The circumstances of discovery are variable. In the majority of cases, it is the man who comes to be consulted after that of the woman. Indeed, the woman is much more inclined to design problems during the first years of marriage. But the main reason is that in our context, the woman is stigmatized by the circle 
that makes her bear the exclusive responsibility. This finding is justified by most authors who agreed that the woman usually consults first in the context of spousal sub-fertility. In our study, nearly half of the patients (42.3\%) were referred to urology after consulting the woman in a gynecologist. More rarely, the patient comes alone for consultation as part of a subfertility assessment. There is a lack of information concerning the involvement of men in the couple's subfertility. Therefore, the consultation should be simultaneous which would allow to quickly locate the responsibilities and to allow an efficient management.

Primary subfertility predominated in our study with $81.1 \%$ of cases. This observation is unanimous in several authors like Benazzouz [11] and Sakande [7] who found respectively $72 \%$ and $75 \%$.

There is a delay in consultation correlated with the lengthening of the duration of the subfertility. The average duration of hypofertility found in our series is 5 years. Punab [12] and Wallerand [8] found an average duration of respectively 3.1 years and 2.6 years which is lower than that of our study. This average, which is quite similar to the various African studies, confirms the delay taken by men before consulting alone or with a partner for a subfertility.

We found in our series, a history of two types of urethritis in $4 \%$ and orchiepididymitis in $2.5 \%$ of patients. Huyghe [13] found a prevalence of urethritis at $59.7 \%$ of cases.

Tobacco can be the cause of male subfertility by significantly decreasing the count, mobility and normal forms with increased spermatozoa with elongated head [14]. This is the case of Diallo [9] and Sakande [7] who found a significant number of smoking patients respectively $22.9 \%$ and $32.5 \%$ of cases. However, the mechanism of occurrence is not fully understood.

Traditional treatment is the first resort of subfertile couples in our context. This finding was also reported by Niang [6] with a rate of $48.8 \%$ of patients having first performed traditional treatment.

Cryptorchidism is very common in hypofertile men. Moreover, a study by Fall B. [15] showed that male subfertility was the main circumstance for the discovery of cryptorchidism. A decrease in testicular volume was found in $19.9 \%$ of patients with a significant predominance of testicular hypotrophy (18.4\%) or more than 15 times the rate of patients with testicular atrophy (1.5\%). This predominance of hypotrophy was also found in primary and secondary infertility. These results are superior to those found by Nevoux P [16], who found a testicular decrease in $11 \%$ of men with subfertility. On the other hand, the proportion of patients with a testicular decrease having a varicocele found by Fall B. [15] (63.6\%) is superior to ours (35\%)

The search for varicocele is fundamental in the clinical evaluation of a hypofertile man. It was found in $33.3 \%$ of cases. This result is below that given by the AFU is $40 \%$ of cases [13]. Loposso et al. [17] found a varicocele in $64.6 \%$. A prevalence of $35.4 \%$ comparable to ours has been found in the work of PUNAB in Estonia [12].

There is a correlation between varicocele, decreased testicular volume and 
hypofertility. For Louis [18], the relationship between varicocele and decreased testicular volume is well established. The exact pathophysiology of the lesions induced by varicocele is not fully understood [6].

Asthenospermia was the most common abnormality in our series, $60.2 \%$ of the cases, and 22.4 patients had azoospermia. These rates are comparable to those found by Menkveld [19] 23\%. For Muratorio [20], asthenospermia represented $55.9 \%$ of cases and that of necrospermia $58.2 \%$.

Boivin [21] noted an improvement in mobility and a decrease in the percentage of morphological abnormalities after varicocele cure. Fisher JRW [22] found a significant improvement in the quality of spermatogenesis in patients with oligospermia after varicocelectomy.

Therapeutic follow-up is also important, it must be done regularly to judge the effectiveness of the treatment [23] [24]. The limits of our study mainly concern the observance of the treatment, the modest income of the patients not allowing them to benefit from assisted procreation.

\section{Conclusion}

The male responsibility in the subfertility is proven. Several factors must be taken into account for a better understanding of the problem. Careful research of these factors will facilitate therapeutic orientation. Better information will reduce the consultation time. A consultation among the gynecologists, the urologists and the biologists must be set up to facilitate the simultaneous treatment of the couple and also to popularize the methods of medical procreation assisted to the profile of the population.

\section{Conflicts of Interest}

The authors declare no conflicts of interest regarding the publication of this paper.

\section{References}

[1] Wagner, L., Tostain, J., et al. (2007) Varicocèle et infertilité masculine: Recommandation Comité Andrologie-AFU 2006. Progrès en Urologie, 17, 12-17. https://doi.org/10.1016/S1166-7087(07)92219-8

[2] Khallouk, A., Tazi, M.F., Fassi, M.J. and Farih, M.H. (2010) L'infertilité masculine: Physiopathologie, bilan et prise en charge. Espérance Médicale, 170, 421-429.

[3] Ndoye, M., Niang, L., Jalloh, M., Labou, I., Kane, R., Diaw, J., Ndiaye, A. and Guèye, S.M. (2008) Azoospermie au Sénégal: Quelle prise en charge à l'heure de l'ICSI? Andrologie, 18, 206-209. https://doi.org/10.1007/BF03040756

[4] Alsalkhan, B., Alrabeeah, K., Delouya, G. and Zini, A. (2016) Epidemiology of varicocèle. Asian Journal of Andrology, 18, 179-181. https://doi.org/10.4103/1008-682X.172640

[5] Inci, K. and Gunay, L.M. (2013) The Role of Varicocele Treatment in the Management of Non-Obstructive Azoospermia. Clinics, 68, 89-98. https://doi.org/10.6061/clinics/2013(Sup01)10

[6] Niang, L., Ndoye, M., Labou, I., Jalloh, M., Kane, R., Diaw, J.J., Ndiaye, A. and 
Guèye, S.M. (2009) Profil épidémiologique et clinique de l'infertilité masculine à l'hôpital général de Grand-Yoff, Sénégal: A propos de 492 cas. Basic and Clinical Andrology, 19, 103-107.

[7] Sakande, J., Kabre, E., Ekue, L.A., Ouedraogo, H.A. and Sawadogo, M. (2012) Relation entre les anomalies du spermogramme et les constituants biochimiques $\mathrm{du}$ liquide séminal de sujets consultant pour hypofertilité masculine à Ouagadougou. International Journal of Biological and Chemical Sciences, 6, 1167-1178.

[8] Wallerand, H., Bernardini, S., Charbannes, E. and Bittard, H. (2003) Infertilité masculine de cause génétique et biologie moléculaire. Progrès en Urologie, 13, 560-563.

[9] Diallo, M.S., Diallo, A.S., Fotso, P., Diallo, Y., Diao, B. and Faye, O. (2015) Semen Abnormality Patterns and Parameters in Male Partners of Infertile Couples in Dakar (Senegal). Open Journal of Urology, 5, 155-160. https://doi.org/10.4236/oju.2015.59024

[10] Eisenberg, M.L., Li, S., Behr, B., Cullen, M.R., Galusha, D., Lamb, D.J. and Lipshultz, L.I. (2014) Semen Quality, Infertility and Mortality in the USA. Human Reproduction, 29, 1567-1574. https://doi.org/10.1093/humrep/deu106

[11] Benazzouz, M.H., Essatara, Y., Sayegh, H., Iken, A., Benslimane, L. and Noulini, Y. (2014) Impact de la varicocèle sur le volume testiculaire et les paramètres spermatique. Pan African Medical Journal, 19, 334-337. https://doi.org/10.11604/pamj.2014.19.334.4693

[12] Punab, M., et al. (2017) Causes of Male Infertility: A 9-Year Prospective Monocentre Study on 1737 Patients with Reduced Total Sperm Counts. Human Reproduction, 32, 18-31.

[13] Huyghe, E., Izard, V., Rigot, J.M., Pariente, J.L. and Tostain, J. (2007) Evaluation de l'homme infertile: Recommandations AFU. Progrès en Urologie, 18, 95-101. https://doi.org/10.1016/j.purol.2007.12.002

[14] Fall, B., Diao, B., Sow, Y., Sarr, A., Fall, P.A., Ndoye, A.K., Ba, M. and Diagne, B.A. (2010) Impact de la varicocélectomie chez les patients ayant une azoospermie non obstructive ou une oligozoospermie sévère. Andrologie, 20, 257-226.

[15] Fall, B., Fall, P.A., Ali, M., Diao, B., Sow, Y., Kaboré, F.A., Sarr, A., et al. (2009) Aspects cliniques, biologiques et thérapeutiques de la cryptorchidie diagnostiquée à l'âge adulte: Analyse d'une série de 69 cas. Andrologie, 19, 168-172.

[16] Nevoux, P., Robin, G., Gonheim, T., boitrelle, F., Rigot, J.M., Marcelli, F., et al. (2009) Varicocele and Infertility: Myth or Reality? Progrès en Urologie, 19, 143.

[17] Loposso, N.K.M., Maole, A.M.L.P., Moningo, M.D., Tshitala, B.D., Bossa, N.J. and Lufuma, L.S. (2010) Oligoasthenoteratospermia (OATS) in Hospital Milieu of Kinshasa: A Retrospective Analysis. Annals of African Medicine, 3, 43-52.

[18] Louis, J.F., Thoma, M.E., Sorensen, D.N., Mc Lain, A.C., King, R.B., Sundaram, R., Keiding, N. and Louis, M.B. (2013) The Prevalence Ok Couple Infertility in the United States from a Male Perspective: Evidence from a Nationnaly Representative Sample. Andrology, 1, 741-748. https://doi.org/10.1111/j.2047-2927.2013.00110.x

[19] Menkveld, R. (2010) Clinical Significance of the Low Normal Sperm Morphology Value as Proposed in the Fifth Edition of the WHO Laboratory Manual for the Examination and Processing of Human Semen. Asian Journal of Andrology, 12, 47-58.

[20] Muratorio, C., Meunier, M., Sonigo, C., Massart, P., Boitrelle, F. and Hugues, J.N. (2013) Varicocèle et infertilité: Où en sommes-nous en 2013? Gynécologie Obstétrique \& Fertilité, 41, 660-666. https://doi.org/10.1016/j.gyobfe.2013.09.012 
[21] Boivin, J., Bunting, L., Collins, J.A. and Nygren, K.G. (2007) International Estimates of Infertility Prevalence and Treatment-Seeking: Potential Need and Demand for Infertility Medical Care. Human Reproduction, 22, 1506-1512.

https://doi.org/10.1093/humrep/dem046

[22] Fisher, J.R.W. and Hammarberg, K. (2012) Psychological and Social Aspects of Infertility in Men: An Overview of the Evidence and Implications for Psychologically Informed Clinical Care and Future Research. Asian Journal of Andrology, 14, 121-129. https://doi.org/10.1038/aja.2011.72

[23] Hovatta, O., Jarna, M., Von, S.M. and Iikka, R. (1995) Testicular Needle Biopsy, Open Biopsy, Epididymal Aspiration and Intracytoplasmic Sperm Injection in Obstructive Azoospemia. Human Reproduction, 10, 2595-2599.

https://doi.org/10.1093/oxfordjournals.humrep.a135752

[24] Tvrda, E., Agarwal, A. and Alkuhaini, N. (2015) Male Reproductive Cancers and Infertility: A Mutual Relationship. International Journal of Molecular Sciences, 16, 7230-7260. https://doi.org/10.3390/ijms16047230 